This is an electronic reprint of the original article. This reprint may differ from the original in pagination and typographic detail.

Author(s): Rissanen, Antti; Ojala, Anne; Dernjatin, Markus; Jaakkola, Jouni; Tiirola, Marja

Title: $\quad$ Methylophaga and Hyphomicrobium can be used as target genera in monitoring saline water methanol-utilizing denitrification

Year: $\quad 2016$

Version:

Please cite the original version:

Rissanen, A., Ojala, A., Dernjatin, M., Jaakkola, J., \& Tiirola, M. (2016). Methylophaga and Hyphomicrobium can be used as target genera in monitoring saline water methanol-utilizing denitrification. Journal of Industrial Microbiology and Biotechnology, 43(12), 1647-1657. https://doi.org/10.1007/s10295-016-1839-2

All material supplied via JYX is protected by copyright and other intellectual property rights, and duplication or sale of all or part of any of the repository collections is not permitted, except that material may be duplicated by you for your research use or educational purposes in electronic or print form. You must obtain permission for any other use. Electronic or print copies may not be offered, whether for sale or otherwise to anyone who is not an authorised user. 


\section{Methylophaga and Hyphomicrobium can be used as target genera in monitoring saline water methanol-utilizing denitrification}

\section{Antti J. Rissanen ${ }^{1,2} *$ Anne Ojala ${ }^{3,4} \cdot$ Markus Dernjatin $^{5} \cdot J^{\prime}$ Aouni Jaakkola ${ }^{5}$ Marja}

Tiirola ${ }^{2}$

${ }^{1}$ Department of Chemistry and Bioengineering, Tampere University of Technology, P.O. Box 541, FI-33101 Tampere, Finland

${ }^{2}$ Department of Biological and Environmental Science, University of Jyväskylä, P.O. Box 35, FI-40014 Jyväskylä, Finland

${ }^{3}$ Department of Environmental Sciences, University of Helsinki, P.O. Box 65, FI00014 Helsinki, Finland

${ }^{4}$ Department of Forest Sciences, University of Helsinki, P.O. Box 27, FI-00014, Helsinki, Finland

${ }^{5}$ SEA LIFE, Helsinki, Tivolitie 10, FI-00510 Helsinki, Finland

*Corresponding author.

E-mail address: antti.rissanen@tut.fi

tel.: +358401981145

fax.: +35833641392

\section{Acknowledgements}

We thank H. Devlin, B. Thamdrup and S. Hallin for comments on an earlier version of this manuscript. This study was funded by Maa- ja Vesitekniikan Tuki ry (A.J.R.) and the Academy of Finland (projects 286642 to A.J.R. and 120089 to M.T.), as well as the European Research Council (ERC) Consolidator project 615146 (M.T.). 
1 Abstract Which bacterial taxonomic groups can be used in monitoring saline water

2 methanol-utilizing denitrification and whether nitrate is transformed into $\mathrm{N}_{2}$ in the process

3 are unclear. Therefore, methylotrophic bacterial communities of two efficiently

4 functioning (nitrate/nitrite reduction was 63-96\%) tropical and cool seawater reactors at a

5 public aquarium were investigated with clone library analysis and 454 pyrosequencing of

6 the 16S rRNA genes. Transformation of nitrate into $\mathrm{N}_{2}$ was confirmed using ${ }^{15} \mathrm{~N}$ labeling

7 in incubation of carrier material from the tropical reactor. Combining the data with

8 previous study results, Methylophaga and Hyphomicrobium were determined to be

9 suitable target genera for monitoring the function of saline water methanol-fed

10 denitrification systems. However, monitoring was not possible at the single species level.

11 Interestingly, potential nitrate-reducing methylotrophs within Filomicrobium and closely

12 related Fil I and Fil II clusters were detected in the reactors suggesting that they also

13 contributed to methylotrophic denitrification in the saline environment.

18 Keywords Methylotrophy · Denitrification - Saline water - Reactor · 16 S rRNA 19

20

21

22

23

24

25

26

27

28

29

30 
33 Introduction

35 Denitrification, step-wise reduction of water-soluble nitrate $\left(\mathrm{NO}_{3}^{-}\right)$via nitrite $\left(\mathrm{NO}_{2}^{-}\right)$to

36 gaseous nitric oxide $(\mathrm{NO})$, nitrous oxide $\left(\mathrm{N}_{2} \mathrm{O}\right)$ and di-nitrogen $\left(\mathrm{N}_{2}\right)$ by facultative

37 anaerobic heterotrophic bacteria, provides an important biotechnological water treatment

38 process for nitrogen $(\mathrm{N})$ removal. Denitrification is mostly a community process, as many

39 denitrifiers perform only partial denitrification reducing $\mathrm{NO}_{3}{ }^{-}$to $\mathrm{NO}_{2}{ }^{-}$or to $\mathrm{N}_{2} \mathrm{O}$, and only

40 some bacterial species are capable of the whole denitrification chain from $\mathrm{NO}_{3}{ }^{-}$to $\mathrm{N}_{2}$ gas

41 [10]. Due to the low C:N ratio of the influent water in many $\mathrm{N}$ removal systems, an

42 external carbon source, usually methanol, is added to the process. Methanol-utilizing

43 denitrification systems are widely applied in municipal wastewater treatment plants [18].

44 In addition, these systems are especially important for reducing toxic inorganic $\mathrm{N}$

45 compounds in closed marine facilities, for example, in public aquaria [21] and aquaculture 46 farms [25].

47 The physicochemical and technical aspects of methanol-utilizing denitrification

48 processes have been comprehensively characterized [18, 24, 25, 26]. However,

49 denitrification is usually measured by $\mathrm{NO}_{\mathrm{x}}$ reduction, that is, the disappearance of $\mathrm{NO}_{3}{ }^{-}$

$50 / \mathrm{NO}_{2}{ }^{-}$[23]. This indirectly measured denitrification rate denotes the conversion of water-

51 soluble $\mathrm{NO}_{\mathrm{x}}{ }^{-}$into gaseous forms, but the proportions of $\mathrm{NO}, \mathrm{N}_{2} \mathrm{O}$ and $\mathrm{N}_{2}$ in the end-

52 product are not specified. Thus far, only a few studies have been conducted on direct

53 measurements of gaseous end-products $[17,27]$. These studies mostly focused on $\mathrm{N}_{2} \mathrm{O}$

54 production $[17,27]$, and the conversion of $\mathrm{NO}_{3}{ }^{-}$to $\mathrm{N}_{2}$ has only very rarely been measured

55 or even confirmed in water treatment facilities [6]. 
Optimal control and operation of wastewater treatment processes would also

57 greatly benefit from microbiological data [27, 43], such as monitoring the presence and

58 abundance of taxonomic groups crucial for system function [27]. The search for potential

59 target taxonomic groups for monitoring saline water methanol-utilizing denitrification

60 processes should be carried out in efficiently functioning systems and should focus on

61 methylotrophic (C1-compound utilizing) organisms as they play a key role in the current

62 processes, by utilizing methanol as an electron donor in denitrification and by

63 transforming methanol into various extracellular organic compounds, which can then be

64 utilized by co-occurring non-methylotrophic denitrifiers [27]. Methylotrophic bacteria of

65 the genera Methylophaga and Hyphomicrobium have been shown to dominate the two

66 previously studied saline water methanol-fed denitrification systems: a moving bed

67 biofilm reactor at a seawater aquarium [3, 21, 22] and a laboratory-scale continuously

68 stirred tank reactor (CSTR) that treat synthetic saline wastewater [32]. In addition to these

69 two genera, Azoarcus and Paracoccus were important methylotrophs in CSTR [32].

70 Further analyses in the aquarium showed the genetic potential of Methylophaga to reduce

$71 \mathrm{NO}_{3}{ }^{-}$to $\mathrm{NO}_{2}{ }^{-}$and Hyphomicrobium to complete the denitrification by converting $\mathrm{NO}_{2}{ }^{-}$

72 into $\mathrm{N}_{2}[2,3,42]$. However, physicochemical and biological variations among bioreactors

73 could lead to differences in the community composition. Thus, other methylotrophs could

74 be important for the function of these systems given that methylotrophy is a quite widely

75 dispersed trait among bacteria [19], and many can also conduct partial or complete

76 denitrification $[4,5,8,12,20,45]$. Therefore, more studies are needed to determine

77 suitable target taxonomic groups for monitoring the function of saline water methanol-fed

78 denitrification processes.

79 This study investigated $\mathrm{NO}_{\mathrm{x}}{ }^{-}$reduction and the bacterial communities of two

80 methanol-utilizing denitrifying bioreactors in a marine fish aquarium operating at two 
81 water circulation temperatures. We aimed to confirm the microbiological transformation

82 of $\mathrm{NO}_{3}{ }^{-}$to $\mathrm{N}_{2}$ using batch incubations and the ${ }^{15} \mathrm{~N}$ tracer technique. Furthermore, we

83 aimed to find suitable target taxonomic groups for monitoring the function of saline water

84 methanol-utilizing denitrification processes. This was achieved via a clone library and 454

85 pyrosequencing analysis of the 16S rRNA genes and comparison of the results for the two

86 study reactors to those for previously studied systems [3, 21, 32]. We specifically focused

87 on the analysis of taxonomic groups that harbor known methylotrophs.

88 Materials and methods

89

Sampling site and sampling for molecular microbiology

The public fish aquarium SEA LIFE Helsinki Finland

93 (https://www.visitsealife.com/helsinki/) is divided into two water recirculation systems

94 (warm tropical, AQUAR_T, and cold North Atlantic, AQUAR_C) and has a total water

95 volume of $420 \mathrm{~m}^{3}$ with $27-34 \mathrm{ppt}$ salinity. Both circulation systems have their own

96 fluidized-bed type denitrification reactors that receive $\mathrm{NO}_{3}{ }^{-}$-rich water from the

97 nitrification stage. The volume of each reactor is $\sim 330 \mathrm{~L}$ of which $\sim 90 \mathrm{~L}$ is the fluidized

98 carrier material bed (oolitic sand, $100 \mathrm{~kg}$, density $=1.5 \mathrm{~kg} / \mathrm{L}$ ). The temperature inside the

99 denitrification reactors of AQUAR_T and AQUAR_C was $23-24{ }^{\circ} \mathrm{C}$ and $18-19{ }^{\circ} \mathrm{C}$,

100 respectively. Two samples of oolitic sand for molecular microbiological analyses were

101 collected twice, on 10 November 2008 and 8 September 2010, from the AQUAR_T and

102 AQUAR_C reactors, in sterile $50 \mathrm{~mL}$ plastic containers and stored at $-20{ }^{\circ} \mathrm{C}$ before

103 processing within 1 to 2 months. The reactors utilized methanol as their carbon source

104 except AQUAR_C in 2008 when a mixture of methanol and saccharose was used until the

105 sampling time point after which only methanol was used.

\section{Denitrification measurements}


109 The $\mathrm{NO}_{\mathrm{x}}{ }^{-}$concentrations inside the reactors, near the reactor outlet $\left(\mathrm{NO}_{\mathrm{x}}{ }^{-}\right.$out $)$and in the

110 inflow water feeding the reactors $\left(\mathrm{NO}_{\mathrm{x}}{ }^{-}\right.$inflow $)$were measured using Spectroquant ${ }^{\circledR}$ nitrate

111 and nitrite test kits (Merck Millipore, Germany) with a Spectroquant ${ }^{\circledR}$ Nova 60

112 photometer (Merck Millipore, Germany) from both reactors 1 to 2 times per month for 2.3

113 years (time period 24 September 2008 to 28 December 2010). The methanol addition

$114\left(\mathrm{Met}_{\mathrm{f}}, \mathrm{mmol} / \mathrm{h}\right)$ and water flow $\left(\mathrm{W}_{\mathrm{f}}, \mathrm{L} / \mathrm{h}\right)$ rates were adjusted by the operators and for this

115 study reported for 1.5 to 2 month periods before bacterial sampling in 2008 and 2010 (24

116 September to 10 November 2008 and 13 July to 8 September 2010). Hourly NO $_{\mathrm{x}}{ }^{-}$loads

$117\left({ }_{\mathrm{L}} \mathrm{NO}_{\mathrm{x}}{ }^{-}\right.$inflow and ${ }_{\mathrm{L}} \mathrm{NO}_{\mathrm{x}}{ }^{-}$out, $\left.\mathrm{mmol} \mathrm{N} / \mathrm{h}\right)$ were calculated using the $\mathrm{W}_{\mathrm{f}}$ and $\mathrm{NO}_{\mathrm{x}}{ }^{-}$concentration

118 values for these time periods. Denitrification was then estimated indirectly as the relative

$119 \quad \mathrm{NO}_{\mathrm{x}}{ }^{-}$reduction $(\%)$ :

$$
N O_{x^{-}} \text {reduction }=\frac{\left(N O_{x^{-} \text {inflow }}-N O_{x^{-} \text {out }}\right)}{N O_{x^{-} \text {inflow }}} \times 100
$$

and as the actual $\mathrm{NO}_{\mathrm{x}}{ }^{-}$reduction:

$$
\text { actual } N O_{\mathrm{x}^{-}} \text {reduction }={ }_{\mathrm{L}} N O_{\mathrm{x}^{-} \text {inflow }}-{ }_{\mathrm{L}} N O_{\mathrm{x}}{ }^{-} \text {out, }
$$

123 which was converted into the $\mathrm{NO}_{\mathrm{x}}{ }^{-}$reduction rate of the carrier material $\left(\mu \mathrm{mol} \mathrm{N} / \mathrm{L}_{\mathrm{car}} / \mathrm{h}\right)$.

124 Direct denitrification measurement was performed with bottle incubation in 2010 .

125 Batches of oolitic sand $(\sim 36 \mathrm{~mL})$ collected from the middle of the filter bed in AQUAR_T

126 were put in $120 \mathrm{~mL}$ glass bottles (11 bottles altogether). The bottles were filled with

127 anoxic reactor water by submerging them in the reactor, and while submerged, they were

128 closed with caps that had butyl rubber stoppers. Each bottle was injected with $\sim 219 \mu$ mol

129 ( 7 mg) of methanol and $\sim 50 \mu \mathrm{mol}(\sim 0.7 \mathrm{mg})$ of $\mathrm{NO}_{3}{ }^{-}-\mathrm{N}$, which had a $2 \%{ }^{15} \mathrm{~N}$ isotope

130 label, and then shaken briefly but vigorously. The $\mathrm{NO}_{3}{ }^{-}$stock solution $\left(0.1 \mathrm{M} \mathrm{NO}_{3}{ }^{-} \mathrm{N}\right)$

131 was prepared from $\mathrm{NaNO}_{3}$ and $\mathrm{K}^{15} \mathrm{NO}_{3}{ }^{-}$(Cambridge Isotope Laboratories, Inc., MA,

132 USA). The total $\mathrm{NO}_{3}{ }^{-} \mathrm{N}$ concentration after the addition was $\sim 664 \mu \mathrm{M}$, which is 
133 approximately the same as the average $\mathrm{NO}_{\mathrm{x}}{ }^{-}$inflow concentration $(\sim 688 \mu \mathrm{M})$ during the $\sim 2$ month period before sampling in 2010 . The bottles were incubated non-shaken at 21-22

$135{ }^{\circ} \mathrm{C}$ and sacrificed in batches after $2 \mathrm{~h}$ ( 4 bottles), $6 \mathrm{~h}$ ( 4 bottles) and $21 \mathrm{~h}$ ( 3 bottles) of

136 incubation. One non-incubated water sample taken from the reactor before the incubation

137 periods served as the 0 time point control. The water subsamples were stored in $12 \mathrm{~mL}$

138 borosilicate glass Exetainer@ tubes with screw-capped butyl rubber septa (Labco Ltd.,

139 High Wycombe, UK), and the microbial activity in the vials was terminated by adding 0.1

$140 \mathrm{~mL}$ of $\mathrm{ZnCl}_{2}(1 \mathrm{~g} / \mathrm{mL})$. The concentration and ${ }^{15} \mathrm{~N}$ content of the $\mathrm{N}_{2}$ gas in the water was

141 measured as in Tiirola et al. [41]. Denitrification was calculated as the rate of the total $\mathrm{N}_{2}$

142 gas accumulation and converted to the $\mathrm{N}_{2}$ production rate of the carrier material $(\mu \mathrm{mol}$

$143 \mathrm{~N} / \mathrm{L}_{\mathrm{car}} / \mathrm{h}$ ). In addition, reduction of $\mathrm{NO}_{3}{ }^{-}$to $\mathrm{N}_{2}$ gas was verified by the accumulation of

144 excess ${ }^{15} \mathrm{~N}$-containing $\mathrm{N}_{2}$ gas. The concentration of the excess ${ }^{15} \mathrm{~N}$-containing $\mathrm{N}_{2}$ gas,

145 [excess $\left.{ }^{15} \mathrm{~N}\right]$, was calculated for each sample as

where [ $\left.\mathrm{N}_{2 \text { sample }}\right]$ is the $\mathrm{N}_{2}$ gas concentration in the incubated sample and the at $\%{ }^{15} \mathrm{~N}_{\text {sample }}$

148 and the at $\%{ }^{15} \mathrm{~N}_{\text {zero }}$ are the ${ }^{15} \mathrm{~N}$ content (in \%) of the $\mathrm{N}_{2}$ gas in the incubated and non-

149 incubated (0 time point) samples, respectively.

\section{Molecular microbiological analyses}

153 DNA was extracted from $0.5-0.6 \mathrm{~g}$ of frozen oolitic sand from each sample using glass

154 bead beating and phenol-chlorophorm extraction, which was followed by isopropanol-

$155 \mathrm{NaCl}$ precipitation (pH 8) and dissolution of the DNA pellet in TE buffer.

158 CCGTCAATTCMTTTGAGTTT-3') as previously described [36] but using the following 
159 program: initial denaturation at $95{ }^{\circ} \mathrm{C}$ for $5 \mathrm{~min}$ and 30 cycles of amplification $\left(94{ }^{\circ} \mathrm{C}\right.$ for

$16030 \mathrm{~s}, 53{ }^{\circ} \mathrm{C}$ for $1 \mathrm{~min}, 72{ }^{\circ} \mathrm{C}$ for $3 \mathrm{~min}$ ) and final elongation at $72{ }^{\circ} \mathrm{C}$ for $15 \mathrm{~min}$. The PCR

161 products of the replicate samples were pooled for subsequent cloning and sequencing,

162 which was carried out as previously described [36].

163 To get deeper insight into the bacteria inhabiting the methanol-fed denitrification

164 reactors, the bacterial community in AQUAR_T, which used methanol as the sole carbon

165 source, was studied with 454 pyrosequencing. Equal amounts of nucleic acid extracts from

166 replicate samples of AQUAR_T in 2008 were pooled before the PCR reactions. PCR

167 amplification of the $16 \mathrm{~S}$ rRNA genes using primers $341 \mathrm{~F}\left(5^{\prime}-\right.$

168 CCTACGGGNGGCWGCAG-3’') / 805R (5'-GACTACHVGGGTATCTAATCC-3’),

169 subsequent purification steps and sequencing were performed as previously described

170 [33].

171

172 Sequence analysis

173

174 In the analysis of the clone library sequences, the Mothur program package [38] was used

175 for sequence alignment, chimera-checking (chimera.uchime executable), classification of

176 sequences into operational taxonomic units (OTUs; $97 \%$ identity threshold) and

177 taxonomic classification of the OTUs (using the Ribosomal Database Project database).

178 Variations in the community structure among the samples were analyzed with hierarchical

179 clustering (UPGMA linkage, Bray-Curtis distances) using PAST version 3.09 [13].

180 Representative sequences of the OTUs assigned to taxonomic groups of known

181 methylotrophs derived from the previous literature [8, 19, 21, 22, 32, 45], in this case

182 Hyphomicrobiaceae and Methylophaga, were subjected to phylogenetic tree analyses

183 [neighbor-joining (NJ) method, Kimura-2 distances, pairwise exclusion of gaps] using

184 Mega 5.05 [40]. 
ambiguous nucleotides and homopolymers longer than eight nucleotides) were removed

187 from the 454 pyrosequencing library. Sequences ( $200 \mathrm{bp})$ were thereafter processed as

188 described above for the clone library analysis except phylogenetic trees were not

189 constructed.

190 The 16S rRNA gene sequences of the clone libraries were deposited in the NCBI

191 GenBank (accession numbers KP098736-KP098970, KP098976-KP098984 and

192 KP098989-KP099005). The 454 pyrosequencing data were deposited in the NCBI SRA

193 database (SRX646347).

195 Results

\section{Functioning of denitrifying reactors}

The operator-adjusted $\mathrm{W}_{\mathrm{f}}$ and Met $_{\mathrm{f}}$ were lower in 2010 than in 2008 in both reactors

200 during the 1.5 to 2 month period before bacterial sampling (Table 1). The average hourly

$201 \mathrm{NO}_{\mathrm{x}}{ }^{-}$load in the inflow decreased in AQUAR_T and increased in AQUAR_C from 2008

to 2010 (Table 1). The average molar ratio of the added methanol to the $\mathrm{N}$ load methanol: $\mathrm{NO}_{\mathrm{x}}{ }^{-}-\mathrm{N}_{\text {inflow }}$ (mol:mol) decreased from 2008 to 2010 in both reactors (Table 1).

204 The ratio was higher in AQUAR_C than in AQUAR_T in 2008 and vice versa in 2010 205 (Table 1).

The relative $\mathrm{NO}_{\mathrm{x}}{ }^{-}$reduction, on average, was slightly higher in AQUAR_C (91\%,

207 range: 81-95\%) than in AQUAR_T (86\%, range: 63-96\%) during the 2.3 year

208 monitoring period (24 September 2008 to 28 December 2010, excluding the very low

209 values caused by the pumping and carbon dosage problems on 4 November 2008 in both

210 reactors and on 4 June 2009 in AQUAR_C; Fig. 1). When averaged over the 1.5 to 2

211 month period before the bacterial sampling, the average actual $\mathrm{NO}_{\mathrm{x}}{ }^{-}$reduction rate 
212 expressed per carrier (oolitic sand) volume was lower in 2008 than in 2010 in both

213 reactors (Table 1). The rate was higher in AQUAR_T than in AQUAR_C in 2008 and vice 214 versa in 2010 (Table 1).

215 Bottle incubation tests confirmed that $\mathrm{N}_{2}$ was produced and $\mathrm{NO}_{3}{ }^{-}$was transformed

216 into $\mathrm{N}_{2}$ by microbes in AQUAR_T (Fig. 2). The estimated $\mathrm{N}_{2}$ production rate of the

217 carrier material was $56.4 \mu \mathrm{mol} \mathrm{N} / \mathrm{L}_{\mathrm{car}} / \mathrm{h}$.

218

219

220

221 The clone library analysis of the 16S rRNA genes indicated that the variation in the

222 bacterial community structure was higher between the reactors than between the years

223 (Table 2; Online Resource 1). Variation between the years in the community structure was

224 considerably higher in the cooler reactor AQUAR_C, which was first fed with a mixture

225 of methanol and saccharose, than in the warmer reactor AQUAR_T (Table 2; Online

226 Resource 1).

227 Different taxonomic groups were assigned to a putative methylotrophic function

228 based on the previous literature. The methylotrophic groups detected in the reactors were

229 the genera Methylophaga, Hyphomicrobium, Filomicrobium, as well as clusters Fil I and

230 Fil II, which were more closely related to Filomicrobium than to Hyphomicrobium (Table

231 2; Figs. 3 and 4). Betaproteobacterial methylotrophs were not detected. In the

232 phylogenetic tree, the OTUs assigned to the genus Hyphomicrobium were positioned

233 between the previously assigned Hyphomicrobium clusters I and II [35] (Fig. 3). Most of

234 the OTUs and sequences assigned to Methylophaga clustered close to $M$.

235 nitratireducenticrescens, whereas one of the OTUs had its closest relative in $M$.

236 thiooxydans (Fig. 4). 
The relative abundance of the putative methylotrophs was considerably higher in the warmer reactor AQUAR_T than in the cooler reactor AQUAR_C in both years (Table 2). In addition, methylotrophs were more abundant in 2010 than in 2008 in AQUAR_C

240 whereas the opposite took place in AQUAR_T (Table 2). The relative abundance of 241 Methylophaga was considerably higher in the warmer reactor AQUAR_T than in the 242 cooler reactor AQUAR_C (Table 2). In AQUAR_C, Methylophaga were absent in 2008 243 and present at very low numbers in 2010. Correspondingly, there was a higher abundance 244 of Methylophaga in 2010 than in 2008 in AQUAR_T (Table 2). Methylophaga in 245 AQUAR_T had their closest relative in M. nitratireducenticrescens, whereas those in 246 AQUAR_C were most closely related to M. thiooxydans (Fig. 4). Of the family

247 Hyphomicrobiaceae, Hyphomicrobium were much more abundant in the warmer reactor

248 AQUAR_T than in the cooler reactor AQUAR_C. There was a higher abundance of 249 Hyphomicrobium in 2010 than in 2008 in AQUAR_C and vice versa in AQUAR_T (Table

250 2). In contrast, the bacteria of the Fil I cluster were much more abundant in AQUAR_C

251 than in AQUAR_T (Table 2). In AQUAR_T, Fil I bacteria were absent in 2008 and 252 present at very low abundance in 2010. Correspondingly, there was a higher abundance of 253 Fil I bacteria in 2010 than in 2008 in AQUAR_C. Fil II cluster bacteria were present in 254 low abundance in both reactors and were absent in AQUAR_T in 2010 (Table 2).

255 Filomicrobium cluster bacteria were present in low abundance and only in AQUAR_T 256 (Table 2; Fig. 3).

The relative abundance of other bacteria also varied between reactors and years and 258 was generally higher in AQUAR_C than in AQUAR_T (Table 2). Within 259 Gammaproteobacteria, there was a considerably large group of unclassified 16S rRNA 260 gene sequences that probably represented clades without cultured representatives (Table 261 2). Of Alphaproteobacteria (other than methylotrophs), Rhodobacteraceae and 
262 Phyllobacteriaceae as well as non-methylotrophic Hyphomicrobiaceae within Maritalea

263 and Mar I clusters were detected (Table 2; Fig. 3). According to BLAST searches [1] of

264 the NCBI nr-database, the detected Rhodobacteraceae were most closely related to the

265 non-methylotrophic genus Roseovarius. Of the Proteobacteria, also Deltaproteobacteria

266 were present. Other detected phyla were Acidobacteria, Actinobacteria, Bacteroidetes,

267 Chloroflexi, Deferribacteres, Planctomycetes and Spirochaetes (Table 2).

268 There were differences in the results of the clone library analysis and 454

269 pyrosequencing (Table 2). Most importantly, 454 pyrosequencing had lower resolution to

270 detect Alphaproteobacteria or resolve different genera within Hyphomicrobiaceae and

271 resulted in a higher proportion of unclassified bacterial sequences than the clone library

272 analysis (Table 2). Since high taxonomic resolution was necessary to identify clusters

273 especially within Hyphomicrobiaceae, the focus in this study was on the clone library

274 results.

275

276 Discussion

277

278 Both study reactors removed $\mathrm{N}$ very efficiently. The relative $\mathrm{NO}_{\mathrm{x}}{ }^{-}$reduction was even

279 slightly higher than measured at other methanol-fed sea water denitrification bioreactors

280 that reduced 65-90\% [22] and up to $88 \%$ [24] of $\mathrm{NO}_{\mathrm{x}}^{-}$. In contrast, the average actual

$281 \mathrm{NO}_{\mathrm{x}}{ }^{-}$reduction rates were within the lower end of the range $\left(300-9000 \mu \mathrm{mol} \mathrm{N} / \mathrm{L}_{\mathrm{car}} / \mathrm{h}\right)$

282 measured at other systems $[21,23,24]$. The differences in the actual $\mathrm{NO}_{\mathrm{x}}{ }^{-}$reduction rates

283 are mostly due to $3-10$ times higher $\mathrm{N}$ loads (as expressed per carrier volume) in the

284 previously studied reactors $[23,24]$. However, the differences can be also partially

285 attributed to the use of deaeration systems to remove $\mathrm{O}_{2}$ in the inflow and the amendment

286 of the trace metal solution in the previously studied reactors, which enhanced 
287 denitrification $[21,23]$. To our knowledge, this is the first study of saline water methanol-

288 utilizing denitrification systems that confirmed $\mathrm{NO}_{3}{ }^{-}$is reduced to $\mathrm{N}_{2}$. However, the $\mathrm{N}_{2}$

289 production measured in the batch tests was only 6-7\% of the actual $\mathrm{NO}_{\mathrm{x}}{ }^{-}$reduction rates

290 in the AQUAR_T reactor. This difference is very likely due to the lack of shaking during

291 incubation, which reduced the contact between $\mathrm{NO}_{3}{ }^{-}$and the bacteria on the carrier

292 material. However, the possible formation of other gases, $\mathrm{N}_{2} \mathrm{O}$ [17] and $\mathrm{NO}$, during the

293 incubation periods can also explain a small part of this discrepancy.

294 Combining the results from the two study reactors and the two previously studied

295 systems $[3,21,32]$ shows that putative methylotrophic bacteria belonging to

296 Methylophaga and Hyphomicrobium are very common in efficiently functioning saline

297 water methanol-fed denitrification systems. This result indicates that these bacteria are

298 crucial for the function of the process. Thus, these two genera can serve as targets when

299 monitoring the function of saline-water methanol-utilizing denitrification systems.

300 However, there were considerable species-level differences between the systems.

301 Hyphomicrobium nitrativorans, which dominated in a previously studied system [3, 21],

302 were not found at all in the AQUAR reactors, and Methylophaga nitratireducenticrescens,

303 which inhabited a previously studied reactor [3] and AQUAR_T, were not found in

304 AQUAR_C. Thus, no single Methylophaga or Hyphomicrobium species can be

305 determined for use as a general target species for monitoring the function of saline water

306 methanol-fed denitrification systems.

307 Interestingly, this study is also the first to show that members of Filomicrobium

308 sp. and Filomicrobium-related Fil I and Fil II clusters can be abundant in efficiently

309 functioning saline water methanol-fed denitrification systems. In addition to results from

310 cultivation-based [45] and genomic [14] studies of Filomicrobium strains, further

311 confirmation of the bacteria's methylotrophic metabolism was provided by the concurrent 
312 increase in the relative abundance of Hyphomicrobium, Methylophaga and Fil I bacteria in

313 AQUAR_C from 2008 to 2010 when the C source changed from saccharose+methanol to

314 solely methanol. In 2008, the methylotrophs were probably over-competed by more

315 efficiently growing non-methylotrophs, for example, in Bacteroidetes, Rhodobacteraceae

316 and Maritalea. Furthermore, the concurrent decrease in Hyphomicrobium and Fil II

317 bacteria in AQUAR_T from 2008 to 2010 could due to the decrease in the availability of

318 methanol (a decrease in $\mathrm{Met}_{\mathrm{f}}$ and methanol: $\mathrm{NO}_{\mathrm{x}}-\mathrm{N}_{\text {inflow }}$ before sampling).

319 Previous studies also suggest that Filomicrobium participate in denitrification by

320 dissimilatory reduction of $\mathrm{NO}_{3}{ }^{-}$to $\mathrm{NO}_{2}^{-}[14,45]$. Thus, in addition to Methylophaga [2, 3],

321 Filomicrobium, Fil I and Fil II bacterial clusters could couple methylotrophy with the

322 reduction of $\mathrm{NO}_{3}^{-}$to $\mathrm{NO}_{2}^{-}$and supply it for denitrifiers capable of further denitrification

323 steps [3]. However, previously studied strains of Methylophaga thiooxydans [7] and M.

324 nitratireducenticrescens [42] also had the $\mathrm{NO}_{2}^{-}$reductase gene, although it was truncated

325 in M. nitratireducenticrescens [42]. In addition, M. nitratireducenticrescens had genes for

$326 \mathrm{NO}$ and $\mathrm{N}_{2} \mathrm{O}^{-}$reduction [42]. This suggests that Methylophaga species coupling

327 methylotrophy to $\mathrm{NO}_{2}^{-}, \mathrm{NO}$ and $\mathrm{N}_{2} \mathrm{O}$ reduction could exist in nature and in saline water

328 methanol-fed denitrification systems. Since only a few Filomicrobium strains have been

329 characterized for their metabolic potential [14, 45], it is possible that some species within

330 Filomicrobium, Fil I and Fil II clusters are also capable of this.

331 Thorough comparative analyses of the factors that affect the growth and activity of

332 Filomicrobium and Hyphomicrobium species do not exist. Therefore, many possible

333 factors might have affected the genera- and species-level variation of Hyphomicrobiaceae

334 between the AQUAR reactors and previously studied systems [3, 21]. In a comparison of

335 denitrifying Hyphomicrobium species, $\mathrm{NO}_{3}{ }^{-}$significantly affected the growth and activity

336 of Hyphomicrobium species with $H$. nitrativorans growing and denitrifying at higher $\mathrm{NO}_{3}{ }^{-}$ 
337 concentrations than the other studied species, H. zavarzinii and H. denitrificans [30].

338 Thus, the considerably lower $\mathrm{N}$ loads could explain the presence and dominance of

339 Hyphomicrobium species other than H. nitrativorans in the AQUAR reactors. Similarly,

340 Filomicrobium, Fil I and Fil II bacteria could have been favored in the lower N load

341 conditions that prevail in the AQUAR system. Furthermore, $\mathrm{O}_{2}$ constantly enters AQUAR

342 reactors due to the lack of a preceding deaeration step but is rapidly consumed there based

343 on the anoxic conditions $\left(\left[\mathrm{O}_{2}\right]<0.1 \mathrm{mg} / \mathrm{L}\right.$, below the detection limit of the $\mathrm{O}_{2}$ probe $)$ that

344 prevail inside the reactors [9]. Thus, variation in the $\mathrm{O}_{2}$ availability between the systems

345 can also explain the differences in the bacterial communities. Part of the Hyphomicrobium

346 and Filomicrobium OTUs in the AQUAR reactors may have been favored by $\mathrm{O}_{2}$.

347 Analogously, as in aerobic methane oxidation coupled with denitrification (AME-D) [46],

348 these bacteria could have contributed to the overall denitrification performance by

349 consuming $\mathrm{O}_{2}$ and by aerobically converting methanol to organic substrates utilizable by

350 non-methylotrophic denitrifiers. However, in addition to variating $\mathrm{NO}_{3}{ }^{-}$and $\mathrm{O}_{2}$,

351 differences in the inocula (the original bacterial community that colonized the reactors)

352 and in the carrier materials between the reactors as well as the amendment of the trace

353 metal solution and the higher addition of methanol in the previously studied systems [3,

$35421,22]$ could have also affected the differences in the bacterial communities.

355 The lower relative abundance of methylotrophs in the cooler reactor AQUAR_C

356 than in AQUAR_T can be first explained by the saccharose addition in 2008 leading to

357 over-competition of non-methylotrophic organisms in AQUAR_C. In 2010, the difference

358 can be attributed to the lower availability of methanol (lower $\mathrm{Met}_{\mathrm{f}}$ and methanol: $\mathrm{NO}_{\mathrm{x}}{ }^{-}$

359 inflow) in AQUAR_C. Variation in the availability of methanol can also explain the lower

360 abundance of Hyphomicrobium and Methylophaga and the higher abundance of Fil I

361 bacteria in AQUAR_C than in AQUAR_T. However, differences in temperature could 
362 also play a role here since the lowest limits of the growth temperature ranges of

363 Methylophaga (M. nitratireducenticrescens, $\left.15-37^{\circ} \mathrm{C}\right)[42]$ and Hyphomicrobium $(H$.

364 nitrativorans, $15-35^{\circ} \mathrm{C}$ ) [29] are higher than that of Filomicrobium (e.g., F. insigne, 4-45

$365{ }^{\circ} \mathrm{C}$ ) [45], which indicates that Filomicrobium-related Fil I bacteria grew better in the

366 cooler AQUAR_C reactor. The growth temperature range of $M$. thiooxydans, the closest

367 cultured relative of Methylophaga in AQUAR_C, is not known. However, the absence of

368 M. thiooxydans in the previously studied sea water reactor with a slightly lower

369 temperature, $16-18{ }^{\circ} \mathrm{C}[3]$, than in AQUAR_C, $18-19{ }^{\circ} \mathrm{C}$, suggests that temperature

370 variations do not explain the differences in the Methylophaga species between AQUAR_C

371 and AQUAR_T. M. thiooxydans can grow on a wider range of carbon substrates

372 (methanol, fructose, monomethylamine) than M. nitratireducenticrescens (methanol) [42].

373 Thus, differences in the Methylophaga species between the reactors could be explained by

374 M. thiooxydans surviving better with lower methanol availability.

375 Many other detected phyla, that is, Acidobacteria, Actinobacteria, Bacteroidetes,

376 Chloroflexi, Deferribacteres, Planctomycetes and Proteobacteria (other than the detected

377 methylotrophs), contain species capable of either partial or complete denitrification [11,

$37827,37,39,44]$ suggesting that they contribute to the overall denitrification performance of

379 the AQUAR reactors and utilize the organic compounds produced by methylotrophs.

380 However, recent cultivation studies have shown that methylotrophy is present within

381 Bacteroidetes [28] and Actinobacteria [15]. In addition, DNA stable isotopic probing

382 (SIP) analyses, although not able to distinguish between direct $\mathrm{C} 1$ utilization and cross-

383 feeding, raise speculation about the existence of unclassified methylotrophic

384 Gammaproteobacteria [31], as well as methylotrophic members within Bacteroidetes,

385 Deferribacteres [16] and Acidobacteria [34]. Further studies are needed to show whether

386 members of these groups couple methylotrophy with denitrification in saline water 
systems and could also be considered potential target taxonomic groups for monitoring purposes.

\section{Conclusions}

391

392 This study confirmed that $\mathrm{NO}_{3}$ was transformed into $\mathrm{N}_{2}$ in a functioning saline water

393 methanol-fed denitrification system. Combining the results of this study with those of

394 previous studies show that Methylophaga and Hyphomicrobium can serve as target genera

395 in monitoring the function of saline water methanol-utilizing denitrification systems.

396 However, species-level differences among the systems, stemming from differences in the

397 physicochemical and biological conditions, prevent the determination of individual

398 Methylophaga or Hyphomicrobium species to be used as general target species in process

399 monitoring. Interestingly, other bacteria with potential methylotrophic and $\mathrm{NO}_{3}{ }^{-}$-reducing

400 metabolism, within Filomicrobium and Fil I and Fil II clusters, were found, suggesting

401 they also contributed to saline water methylotrophic denitrification. Whether bacteria

402 within Methylophaga, Filomicrobium, Fil I and Fil II clusters can only reduce $\mathrm{NO}_{3}{ }^{-}$to

$403 \mathrm{NO}_{2}{ }^{-}$or reduce $\mathrm{NO}_{2}^{-}, \mathrm{NO}$ and $\mathrm{N}_{2} \mathrm{O}$, and whether other detected bacteria are able to couple

404 methylotrophy with denitrification in the saline water denitrification bioreactors, is still to

405 be resolved. These studies should employ high-throughput culturing methods to isolate

406 target organisms, as well as metagenomics and metatranscriptomics.

409 Conflict of interest The authors declare that they have no conflict of interest. 


\section{References}

1. Altschul SF, Madden TL, Schäffer AA, Zhang J, Zhang Z, Miller W, Lipman DJ (1997) Gapped BLAST and PSI-BLAST: a new generation of protein database search programs. Nucleic Acids Res 25:3389-3402

2. Auclair J, Lépine F, Parent S, Villemur R (2010) Dissimilatory reduction of nitrate in seawater by a Methylophaga strain containing two highly divergent narG sequences. ISME J 4:1302-1313

3. Auclair J, Parent S, Villemur R (2012) Functional diversity in the denitrifying biofilm of the methanol-fed marine denitrification system at the Montreal Biodome. Microb Ecol 63:726-735

4. Baytshtok V, Lu H, Park H, Kim S, Yu R, Khandran K (2009) Impact of varying electron donors on the molecular microbial ecology and biokinetics of methylotrophic denitrifying bacteria. Biotechnol Bioeng 102:1527-1536

5. Beck DAC, McTaggart TL, Setboonsarng U, Vorobev A, Kalyuzhnaya MG, Ivanova N, Goodwin L, Woyke T, Lidstrom ME, Chistoserdova L (2014) The expanded diversity of Methylophilaceae from Lake Washington through cultivation and genomic sequencing of novel ecotypes. PLoS ONE 9:e102458

6. Bernet N, Delgenes N, Akunna JC, Delgenes JP, Moletta R (2000) Combined anaerobic-aerobic SBR for the treatment of piggery wastewater. Water Res 34:611619

7. Boden R, Ferriera S, Johnson J, Kelly DP, Murrell JC, Schäfer H (2011) Draft genome sequence of the chemolithoheterotrophic, halophilic methylotroph Methylophaga thiooxydans DMS010. J Bacteriol 193:3154-3155

8. Chistoserdova L, Kalyuzhnaya MG, Lidstrom ME (2009) The expanding world of methylotrophic organisms. Annu Rev Microbiol 63:477-499

9. Dernjatin M (2008) Leijuva-alustaisen denitrifikaatioprosessin optimointi suljetussa kiertovesijärjestelmässä. MsC thesis, University of Helsinki, Helsinki, Finland (in Finnish)

10. Gentile ME, Nyman JL, Criddle CS (2007) Correlation of patterns of denitrification instability in replicated bioreactor communities with shifts in the relative abundance and the denitrification patterns of specific populations. ISME J 1:714-728

11. Gittel A, Kofoed MVW, Sørensen KB, Ingvorsen K, Schramm A (2012) Succession of Deferribacteres and Epsilonproteobacteria through a nitrate-treated hightemperature oil production facility. Syst Appl Microbiol 35:165-174

12. Hagman M, Nielsen JL, Nielsen PH, Jansen J la C (2008) Mixed carbon sources for nitrate reduction in activated sludge-identification of bacteria and process activity studies. Water Res 42:1539-1546

13. Hammer $\varnothing$, Harper DAT, Ryan PD (2001) PAST: paleontological statistics software package for education and data analysis. Palaeontol Electron 4

14. Henriques AC, De Marco P (2015) Complete genome sequences of two strains of "Candidatus Filomicrobium marinum," a methanesulfonate-degrading species. Genome Announc 3:e00160-15

15. Hung WL, Wade WG, Boden R, Kelly DP, Wood AP (2011) Facultative methylotrophs from the human oral cavity and methylotrophy in strains of Gordonia, Leifsonia, and Microbacterium. Arch Microbiol 193:407-417

16. Jensen S, Neufeld JD, Birkeland NK, Hovland M, Murrell JC (2008) Methane assimilation and trophic interactions with marine Methylomicrobium in deep-water coral reef sediment off the coast of Norway. FEMS Microbiol Ecol 66:320-330 
17. Kampschreur MJ, Temmink H, Kleerebezem R, Jetten MSM, van Loosdrecht, MCM (2009) Nitrous oxide emission during wastewater treatment. Water Res 43:4093-4103

18. Koch G, Siegrist H (1997) Denitrification with methanol in tertiary filtration. Water Res 31:3029-3038 300:1-10

20. Kumaresan D, Wischer D, Hillebrand-Voiculescu AM, Murrell JC (2015) Draft genome sequences of facultative methylotrophs, Gemmobacter sp. strain LW1 and Mesorhizobium sp. strain 1M-11, isolated from Movile Cave, Romania. Genome Announc 3:e01266-15

21. Labbé N, Juteau P, Parent S, Villemur R (2003) Bacterial diversity in a marine methanol-fed denitrification reactor at the Montreal Biodome, Canada. Microb Ecol 46:12-21

22. Labbé N, Laurin V, Juteau P, Parent S, Villemur R (2007) Microbiological community structure of the biofilm of a methanol-fed, marine denitrification system, and identification of the methanol-utilizing micro-organisms. Microb Ecol 53:621630

23. Labbé N, Parent S, Villemur R (2003) Addition of trace metals increases denitrification rate in closed marine systems. Water Res 37:914-920

24. Labelle M-A, Juteau P, Jolicoeur M, Villemur R, Parent S, Comeau Y (2005) Seawater denitrification in a closed mesocosm by a submerged moving bed biofilm reactor. Water Res 39:3409-3417

25. Lee PG, Lea RN, Dohmann E, Prebilsky W, Turk PE, Ying H, Whitson JL (2000) Denitrification in aquaculture systems: an example of a fuzzy logic control problem. Aquacult Eng 23:37-59

26. Lemmer H, Zaglauer A, Metzner G (1997) Denitrification in a methanol-fed fixedbed reactor. Part 1: Physico-chemical and biological characterization. Water Res 31:1897-1902

27. Lu H, Chandran K, Stensel D (2014) Microbial ecology of denitrification in biological wastewater treatment. Water Res 64:237-254

28. Madhaiyan M, Poonguzhali S, Lee J-S, Lee KC, Sundaram S (2010) Flavobacterium glycines sp. nov., a facultative methylotroph isolated from the rhizosphere of soybean. Int J Syst Evol Microbiol 60:2187-2192

29. Martineau C, Villeneuve C, Mauffrey F, Villemur R (2013) Hyphomicrobium nitrativorans sp. nov., isolated from the biofilm of a methanol-fed denitrification system treating seawater at the Montreal Biodome. Int J Syst Evol Microbiol 63:3777-3781

30. Martineau C, Mauffrey F, Villemur R (2015) Comparative analysis of denitrifying activities of Hyphomicrobium nitrativorans, Hyphomicrobium denitrificans and Hyphomicrobium zavarzinii. Appl Environ Microbiol 81:5003-5014

31. Neufeld JD, Schäfer H, Cox MJ, Boden R, McDonald IR, Murrell JC (2007) Stableisotope probing implicates Methylophaga spp and novel Gammaproteobacteria in marine methanol and methylamine metabolism. ISME J 1:480-491

32. Osaka T, Shirotani K, Yoshie S, Tsuneda S (2008) Effects of carbon source on denitrification efficiency and microbial community structure in a saline wastewater treatment process. Water Res 42:3709-3718

33. Peura S, Eiler A, Bertilsson S, Nykänen H, Tiirola M, Jones RI (2012) Distinct and diverse anaerobic bacterial communities in boreal lakes dominated by candidate division OD1. ISME J 6:1640-1652 
34. Radajewski S, Webster G, Reay DS, Morris SA, Ineson P, Nedwell DB, Prosser JI, Murrell JC (2002) Identification of active methylotroph populations in an acidic forest soil by stable-isotope probing. Microbiology 148:2331-2342

35. Rainey FA, Ward-Rainey N, Gliesche CG, Stackebrandt, E (1998) Phylogenetic analysis and intrageneric structure of the genus and the related genus Filomicrobium. Int J Syst Bacteriol 48:635-639

36. Rissanen AJ, Kurhela E, Aho T, Oittinen T, Tiirola M (2010) Storage of environmental samples for guaranteeing nucleic acid yields for molecular microbiological studies. Appl Microbiol Biotechnol 88:977-984

37. Scheuner C, Tindall BJ, Lu M, Nolan M, Lapidus A, Cheng J-F, Goodwin L, Pitluck S, Huntemann M, Liolios K, Pagani I, Mavromatis K, Ivanova N, Pati A, Chen A, Palaniappan K, Jeffries CD, Hauser L, Land M, Mwrichia R, Rohde M, Abt B, Detter JC, Woyke T, Eisen JA, Markowitz V, Hugenholtz P, Göker M, Kyrpides NC, Klenk H-P (2014) Complete genome sequence of Planctomyces brasiliensis type strain (DSM 5305T), phylogenomic analysis and reclassification of Planctomycetes including the descriptions of Gimesia gen. nov., Planctopirus gen. nov. and Rubinisphaera gen. nov. and emended descriptions of the order Planctomycetales and the family Planctomycetaceae. Stand Genomic Sci 9:10

38. Schloss PD, Westcott SL, Ryabin T, Hall JR, Hartmann M, Hollister EB, Lesniewski RA, Oakley BB, Parks DH, Robinson CJ, Sahl JW, Stres B, Thallinger GG, Van Horn DJ, Weber CF (2009) Introducing mothur: open-source, platform-independent, community-supported software for describing and comparing microbial communities. Appl Environ Microbiol 75:7537-7541

39. Shoun H, Kano M, Baba I, Takaya N, Matsuo M (1998) Denitrification by Actinomycetes and purification of dissimilatory nitrite reductase and azurin from Streptomyces thioluteus. J Bacteriol 180:4413-4415

40. Tamura K, Peterson D, Peterson N, Stecher G, Nei M, Kumar S (2011) MEGA5: Molecular evolutionary genetics analysis using maximum likelihood, evolutionary distance, and maximum parsimony methods. Mol Biol Evol 28:2731-2739

41. Tiirola MA, Rissanen AJ, Sarpakunnas M, Arvola L, Nykänen H (2011) Stable isotope profiles of nitrogen gas indicate denitrification in oxygen-stratified humic lakes. Rapid Commun Mass Spectrom 25:1497-1502

42. Villeneuve C, Martineau C, Mauffrey F, Villemur R (2013) Methylophaga nitratireducenticrescens sp. nov. and Methylophaga frappieri sp. nov., isolated from the biofilm of the methanol-fed denitrification system treating the seawater at the Montreal Biodome. Int J Syst Evol Microbiol 63:2216-2222

43. Wagner M, Loy A, Nogueira R, Purkhold U, Lee N, Daims H (2002) Microbial community composition and function in wastewater treatment plants. Antonie van Leeuwenhoek 81:665-680

44. Ward NL, Challacombe JF, Janssen PH, Henrissat B, Countinho PM, Wu M, Xie G, Haft DH, Sait M, Badger J, Barabote RD, Bradley B, Brettin TS, Brinkac LM, Bruce D, Creasy T, Daugherty SC, Davidsen TM, DeBoy RT, Detter JC, Dodson RJ, Durkin AS, Ganapathy A, Gwinn-Giglio M, Han CS, Khouri H, Kiss H, Kothari SP, Madupu R, Nelson KE, Nelson WC, Paulsen I, Penn K, Ren Q, Rosovitz MJ, Selengut JD, Shrivastava S, Sullivan SA, Tapia R, Thompson LS, Watkins KL, Yang Q, Yu C, Zafar N, Zhou L, Kuske CR (2009) Three genomes from the phylum Acidobacteria provide insight into the lifestyles of these microorganisms in soils. Appl Environ Microbiol 75:2046-2056

45. Wu X-L, Yu S-L, Gu J, Zhao G-F, Chi C-Q (2009) Filomicrobium insigne sp. nov., isolated from an oil-polluted saline soil. Int J Syst Evol Microbiol 59:300-305 
46. Zhu J, Wang Q, Yuan M, Tan GYA, Sun F, Wang C, Wu W, Lee PH (2016) Microbiology and potential applications of aerobic methane oxidation coupled to denitrification (AME-D) process: A review. Water Res 90:203-215

562

563 
Figure captions:

567 Fig. 1 Concentration of $\mathrm{NO}_{\mathrm{x}}{ }^{-}$in the inflow and the outflow and the relative $\mathrm{NO}_{\mathrm{x}}{ }^{-}$reduction in the denitrification reactors, AQUAR_T and AQUAR_C of the sea water aquarium from 24 September

5692008 to 28 December 2010. The sampling dates for the microbial studies (10 November 2008 and

5708 September 2010) are indicated with arrows

571

572 Fig. 2 Concentrations (average $+/$ - standard deviation) and estimated production rates of $\mathrm{N}_{2}$ gas and excess ${ }^{15} \mathrm{~N}$ (in $\mathrm{N}_{2}$ gas) in incubation bottles after $2 \mathrm{~h}(\mathrm{n}=4), 6 \mathrm{~h}(\mathrm{n}=4)$ and $21 \mathrm{~h}(\mathrm{n}=3)$ of incubation (at room temperature) of the carrier material and water from AQUAR_T with methanol and ${ }^{15} \mathrm{~N}$-labeled $\mathrm{NO}_{3}{ }^{-}$. One non-incubated water sample taken from the reactor before the incubation served as the 0 time point control $(\mathrm{n}=1)$. The standard deviations of the $\mathrm{N}_{2}$ and ${ }^{15} \mathrm{~N}$ concentrations at time point $2 \mathrm{~h}$ are very low and masked behind the symbol

578

Fig. 3 Phylogenetic tree (neighbor-joining method) of Hyphomicrobiaceae based on a comparative analysis of 16S rRNA gene sequences in clone libraries showing the phylogenetic position of the operational taxonomic units (OTUs; at $97 \%$ sequence similarity) in AQUAR_C and AQUAR_T in 2008 and 2010 (symbols). Hyphomicrobium clusters I and II were previously defined by Rainey et al. [35]. The numbers in the parentheses after the OTU number indicate the number of sequences within that OTU. The numbers at the nodes indicate the percentage of occurrence in 1000 bootstrapped trees (bootstrap values $>50 \%$ are shown)

587 Fig. 4 Phylogenetic tree (neighbor-joining method) of Methylophaga based on a comparative 588 analysis of $16 \mathrm{~S}$ rRNA gene sequences in clone libraries showing the phylogenetic position of the 589 operational taxonomic units (OTUs; at $97 \%$ sequence similarity) in AQUAR_C and AQUAR_T 590 at 2008 and 2010 (symbols). The numbers in the parentheses after the OTU number indicate the 
591 number of sequences within that OTU. The numbers at the nodes indicate the percentage of

592 occurrence in 1000 bootstrapped trees (bootstrap values $>50 \%$ are shown)

593

594

595 Online Resource figure captions

596

597 Online Resource 1 Hierarchical clustering analysis (UPGMA) of relative abundance of OTUs

598 (using Bray-Curtis distances) in 16S rRNA gene clone library analyses of AQUAR_T and

599 AQUAR_C in 2008 and 2010

600

601

602

603

604

605

606

607

608

609

610

611

612

613

614

615

616

617

618 
Table 1 Average (range) $\left(\mathrm{n}=3\right.$ in both years) in the actual $\mathrm{NO}_{\mathrm{x}}^{-}$reduction rates, $\mathrm{NO}_{\mathrm{x}}^{-}$load rate $\left({ }_{\mathrm{L}} \mathrm{NO}_{\mathrm{x}}^{-}\right.$inflow) and inflow methanol: $\mathrm{NO}_{\mathrm{x}}^{-}-\mathrm{N}^{-}$ratio as well as operator-controlled rates of methanol addition $\left(\mathrm{Met}_{\mathrm{f}}\right)$, saccharose addition and water flow $\left(\mathrm{W}_{\mathrm{f}}\right)$ in the denitrification reactors of AQUAR_T and AQUAR_C in 2008 and 2010 for the 1.5 to 2 month periods before sampling for bacterial DNA (24 September to 10 November 2008 and 13 July to 8 September 2010)

\begin{tabular}{|c|c|c|c|c|}
\hline & AQUAR_T & & AQUAR_C & \\
\hline Year & 2008 & 2010 & 2008 & 2010 \\
\hline Actual $\mathrm{NO}_{\mathrm{x}}{ }^{-}$reduction $\left(\mu \mathrm{mol} \mathrm{N} / \mathrm{L}_{\mathrm{car}} / \mathrm{h}\right)$ & $580^{\mathrm{a}}(60-1020)$ & $890(740-1090)$ & $540^{\mathrm{b}}(290-700)$ & $910(880-950)$ \\
\hline $\operatorname{Met}_{\mathrm{f}}(\mathrm{mmol} \mathrm{C} / \mathrm{h})$ & 158 & 98 & 185 & 85 \\
\hline Saccharose addition $(\mathrm{mmol} \mathrm{C/h})$ & & & 67 & \\
\hline $\mathrm{W}_{\mathrm{f}}(\mathrm{L} / \mathrm{h})$ & 120 & 70 & 110 & 93 \\
\hline${ }_{\mathrm{L}} \mathrm{NO}_{\mathrm{x}}{ }_{\text {inflow }}(\mathrm{mmol} \mathrm{N} / \mathrm{h})$ & $76(70-80)$ & $66 \quad(54-76)$ & $51 \quad(47-54)$ & $66(63-68)$ \\
\hline Methanol: $\mathrm{NO}_{\mathrm{x}}{ }^{-}-\mathrm{N}_{\text {inflow }}(\mathrm{mol}: \mathrm{mol})$ & $2.1(2.0-2.2)$ & $1.5(1.3-1.8)$ & $3.6(3.4-3.9)$ & $1.3(1.3-1.4)$ \\
\hline
\end{tabular}

${ }^{a}$ Excluding values on 4 November 2008 (pumping and carbon dosage problems), the average actual $\mathrm{NO}_{\mathrm{x}}{ }^{-}$reduction rate is $840 \mu \mathrm{mol} \mathrm{N} / \mathrm{L}_{\mathrm{car}} / \mathrm{h}$ (range 660 1020)

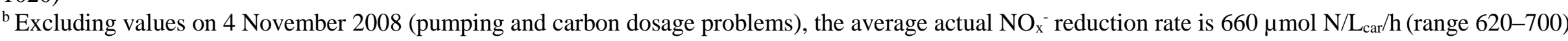
(1) 30 1

63
4 
Table 2 Bacterial community composition (\% of sequences) in denitrifying reactors of sea water aquarium (AQUAR_T and AQUAR_C) based on 16S rRNA gene clone libraries and 454 pyrosequencing. Methanol was used as the sole external carbon source except for AQUAR_C in 2008, when a mixture of methanol and saccharose was used during the period before microbial sampling

\begin{tabular}{|c|c|c|c|c|c|}
\hline & AQUAR_T & AQUAR_T (454) $)^{\mathrm{a}}$ & AQUAR_T & AQUAR_C & AQUAR_C \\
\hline Year (number of sequences) & $2008(72)$ & $2008(1849)$ & $2010(67)$ & $2008(59)$ & $2010(63)$ \\
\hline \multicolumn{6}{|l|}{ Frequency $(\%)^{\mathrm{b}}$ : } \\
\hline Putative methylotrophic & 74 & 38 & 56 & 15 & 30 \\
\hline Alphaproteobacteria & 64 & 35 & 46 & 69 & 30 \\
\hline Hyphomicrobiaceae & 60 & 22 & 31 & 20 & 27 \\
\hline Hyphomicrobium & 53 & - & 25 & 5 & 8 \\
\hline Filomicrobium cluster & 3 & - & 3 & - & - \\
\hline Fil I cluster & - & - & 3 & 7 & 17 \\
\hline Fil II cluster & 4 & - & - & 3 & 2 \\
\hline Maritalea cluster & - & - & - & 2 & - \\
\hline Mar I cluster & - & - & - & 3 & - \\
\hline Rhodobacteraceae & 1 & 2 & - & 32 & - \\
\hline Phyllobacteriaceae & - & 4 & 9 & 2 & 3 \\
\hline Gammaproteobacteria & 22 & 29 & 28 & 7 & 8 \\
\hline Piscirickettsiaceae & 14 & 16 & 25 & - & 3 \\
\hline Methylophaga & 14 & 16 & 25 & - & 3 \\
\hline incertae sedis & - & $<1$ & - & - & 3 \\
\hline unclassified & 8 & 13 & 3 & 7 & - \\
\hline Deltaproteobacteria & 3 & 2 & 7 & - & 5 \\
\hline Acidobacteria & - & - & - & - & 3 \\
\hline Actinobacteria & 1 & $<1$ & 1 & 3 & 2 \\
\hline Bacteroidetes & 3 & 7 & 6 & 19 & 14 \\
\hline Chloroflexi & 3 & 3 & 1 & - & 19 \\
\hline Deferribacteres & - & - & - & - & 2 \\
\hline Planctomycetes & - & 4 & - & - & 10 \\
\hline Spirochaetes & - & $<1$ & - & - & 2 \\
\hline Unclassified + others & 4 & 20 & 11 & 2 & 5 \\
\hline
\end{tabular}


${ }^{\mathrm{b}}$ Classification was performed using the RDP database in Mothur and with phylogenetic tree analysis (Fig. 3). Assignment to methylotrophic function was based on previous literature. Frequencies are given as percentages $(\%)$ of the total number of sequences in a sample 
673
674

Figure 1

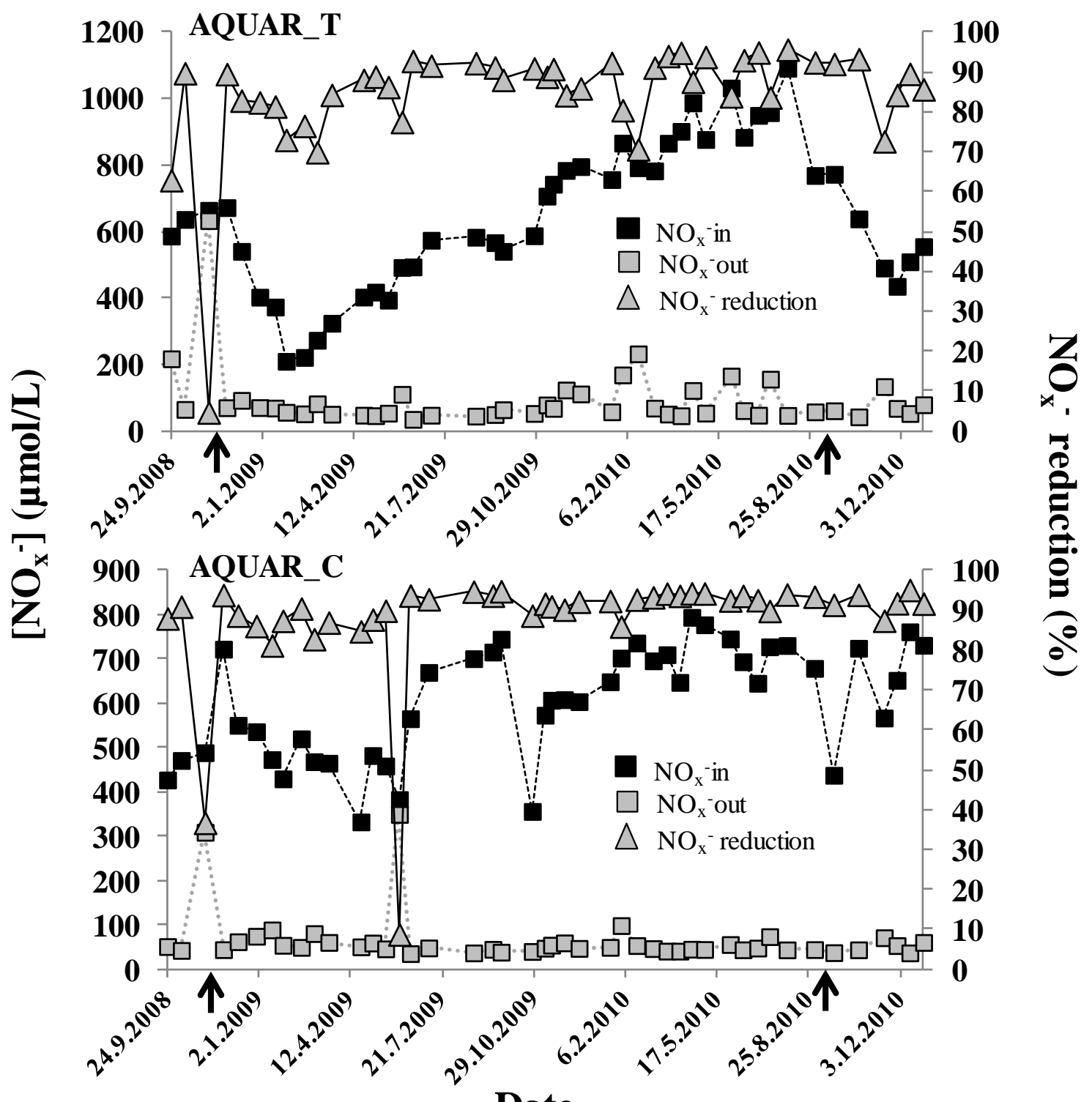

675

Date

677

678

679

680

681

682

683

684 
685 Figure 2

686

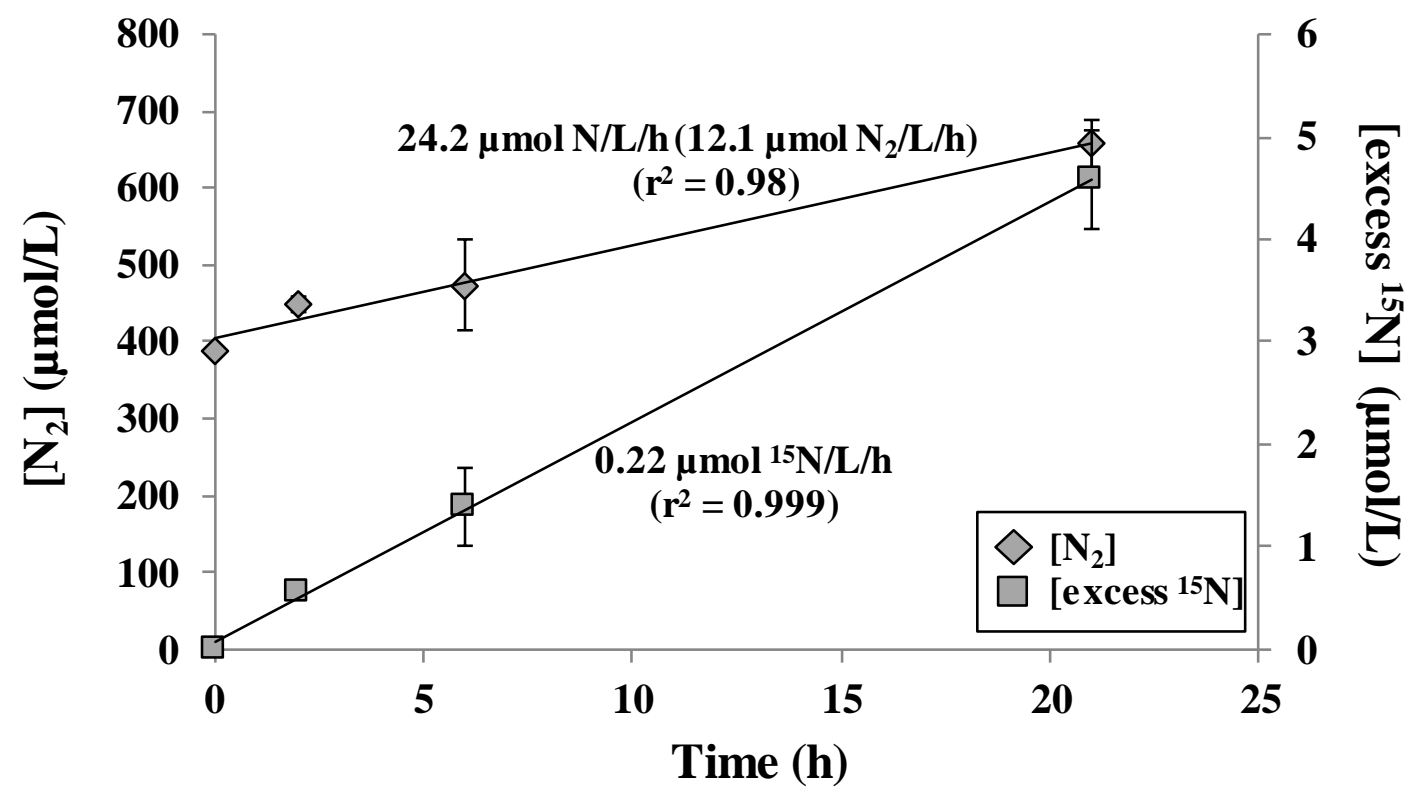

687

688

689

690

691

692

693

694

695

696

697

698

699

700

701

702

703 


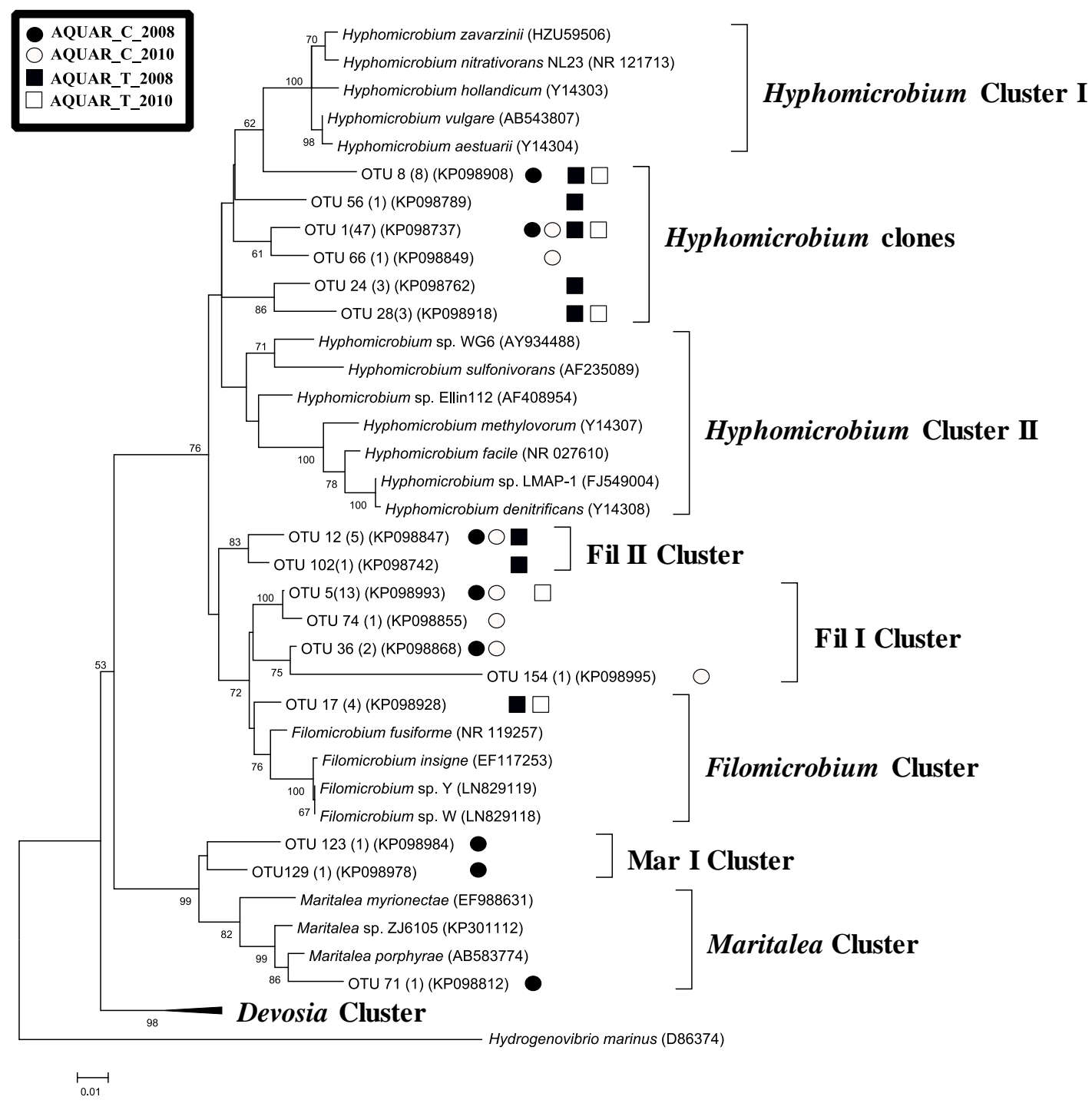


$716 \quad$ Figure 4

717

AQUAR_C_2008

AQUAR_C_2010

AQUAR_T_2008

AQUAR_T_2010

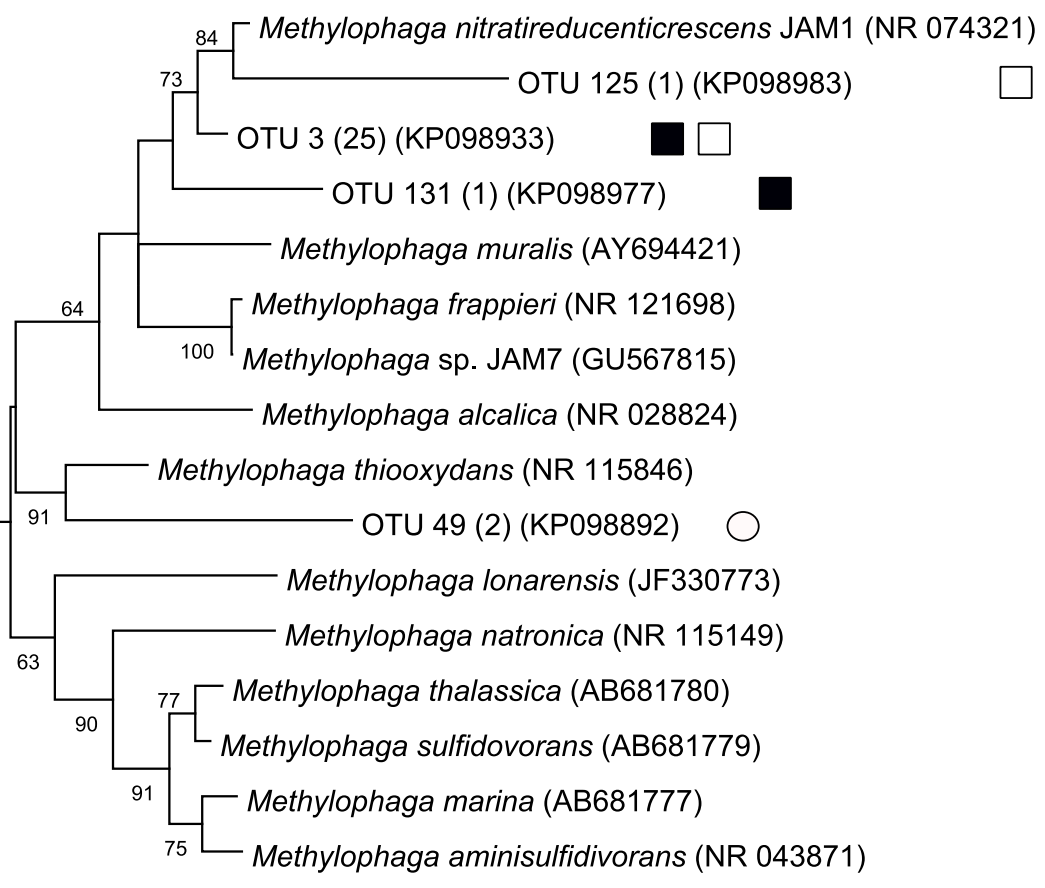

Bradyrhizobium iriomotense (AB300992)

718

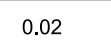

719

720

721

722

723

724

725

726

727

728

729

730

731

732 
Online Resources

Journal: J Ind Microbiol Biotechnol

Title: Methylophaga and Hyphomicrobium can be used as target genera in monitoring saline water methanol-utilizing denitrification

Authors: Antti J. Rissanen ${ }^{1,2 *}$, Anne Ojala, Markus Dernjatin, Jouni Jaakkola \& Marja Tiirola

${ }^{1}$ Department of Chemistry and Bioengineering, Tampere University of Technology, P.O. Box 541, FI-33101 Tampere, Finland

${ }^{2}$ Department of Biological and Environmental Science, University of Jyväskylä, P.O. Box 35, FI-40014 Jyväskylä, Finland

*Corresponding author email-address: antti.rissanen@tut.fi

Online Resource 1

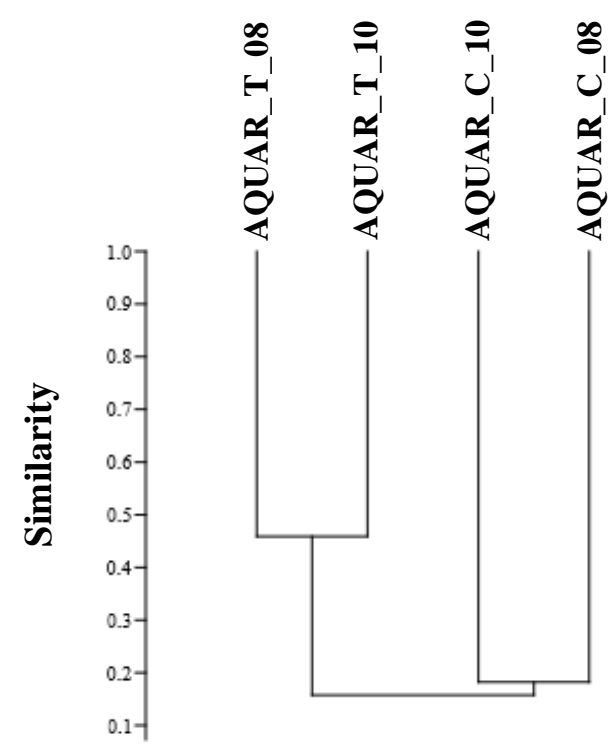

755 Online Resource 1 Hierarchical clustering analysis (UPGMA) of relative abundance of OTUs

756 (using Bray-Curtis distances) in 16S rRNA gene clone library analyses of AQUAR_T and 